\title{
Conjugation at the oligonucleotide level based on isoxazole phosphoramidites generated by click chemistry
}

\author{
Colin Freeman, Aisling Ni Cheallaigh, Frances Heaney* \\ Department of Chemistry, National University of Ireland, Maynooth, Co. Kildare, Ireland
}

\section{A R T I C L E I N F O}

\section{Article history:}

Received 2 February 2011

Received in revised form 9 June 2011

Accepted 24 June 2011

Available online 23 July 2011

\begin{abstract}
A B S T R A C T
The versatility of the isoxazole generating nitrile oxide-alkyne Huisgen cycloaddition for provision of chemically modified oligonucleotides has been extended; in a novel approach isoxazole conjugated oligodeoxyribonucleotides have been constructed by phosphoramidite chemistry of isoxazole derivatives previously generated by nitrile oxide-alkyne click chemistry. The conjugation involves manual solid phase synthesis at room temperature in aqueous ethanol and proceeds in high yield.
\end{abstract}

(c) 2011 Elsevier Ltd. All rights reserved.

\section{Introduction}

Huisgen cycloaddition reactions performed on DNA substrates represent a powerful approach to chemically modified oligonucleotides, in particular the $\mathrm{Cu}(\mathrm{I})$ catalysed azide-alkyne triazole forming reaction has received much attention. ${ }^{1}$ However, we and others have reported attributes of the $[3+2]$-cycloaddition reaction of nitrile oxides and nitrones as a viable, catalyst free, regioselective alternative for the formation of functionalised nucleosides and oligonucleotides. ${ }^{2-6}$ In previously reported work the alkyne partner was introduced to the resin supported oligonucleotide, and subsequent cycloaddition was conducted directly on the solid phase. The objective of the current work was to develop an alternative, modular strategy, whereby modified oligonucleotides could be constructed by coupling of isoxazole phosphoramidite building blocks previously generated by click chemistry. The alternative strategies, where the key cycloaddition reaction is conducted on-, or off-resin, are shown retrosynthetically, in Fig. 1. The attractions of on-resin click chemistry for oligonucleotide conjugation are already well known. ${ }^{1}$ Potential benefits of the off-resin approach, (a), may include ease of operation, particularly with regard to scale-up and functional group compatibility. Dipolar cycloadditions present a robust synthetic strategy for heterocycle formation, and it is the hypothesis of this paper that if either the dipole or the dipolarophile have a pendant hydroxy group, then following cycloaddition and phosphoramidite formation oligonucleotide conjugation can be achieved in a catalyst free environment. Certainly off-resin cycloaddition will serve to increase the versatility of 'click chemistry' for oligonucleotide conjugation and it could be used as

\footnotetext{
* Corresponding author. Tel.: +3531708 3802; fax: +353 1708 3815; e-mail address: mary.f.heaney@nuim.ie (F. Heaney).
}

a complement to solid phase oximation or CuAAC (copper catalysed azide alkyne cycloaddition) approaches to DNA conjugates and, in theory, be applied for the reliable introduction of a variety of reporting or targeting groups into DNA.

Approaches to chemically modified oligonucleotides using building blocks previously prepared by CuAAC chemistry have been reported. In one application, oligodeoxyribonucleotide glycoconjugates have been generated by solid-supported oximation of aminooxy terminated oligonucleotides with glycoclusters constructed by click chemistry. ${ }^{7}$ In other applications phosphoramidite derivatives of click chemistry derived triazole monomers have been utilised, most frequently the triazole moiety is borne at the C-5 position of functionalised pyrimidine bases including deoxyuridines, ${ }^{8-10}$ cytidines ${ }^{11}$ and thymidines, ${ }^{12}$ however, the triazole unit has also been sited at the $5^{\prime}$-position of the sugar ${ }^{13}$ and as a spacer between the base and sugar moieties. ${ }^{14}$ Finally, non-canonical ${ }^{15}$ and non-nucleosidic ${ }^{16}$ triazole phosphoramidites have also been reported. In contrast, whilst isoxazoles are an interesting heterocyclic family with diverse applications, isoxazole bearing phosphoramidites are not well known. To the best of our knowledge, the D-threoninol derived 1, Fig. 2, prepared for inclusion in a library of cyclic oligonucleotides targeted to the Hepatitis $C$ virus, NS5B, represents the only known example. ${ }^{17}$

\section{Results and discussions}

The retrosynthetic approach set out in Fig. 1(a) requires isoxazole building blocks equipped with a pendant hydroxy functionality to act as a handle for ultimate conversion to phosphoramidite monomers. We intended to prepare the isoxazole from an in situ generated, nitrile oxide-alkyne cycloaddition, (NOAC), and believed the isomeric hydroxyethoxybenzaldehyde oximes $\mathbf{2 a}-\mathbf{c}$ represented an ideal platform to explore the concept 


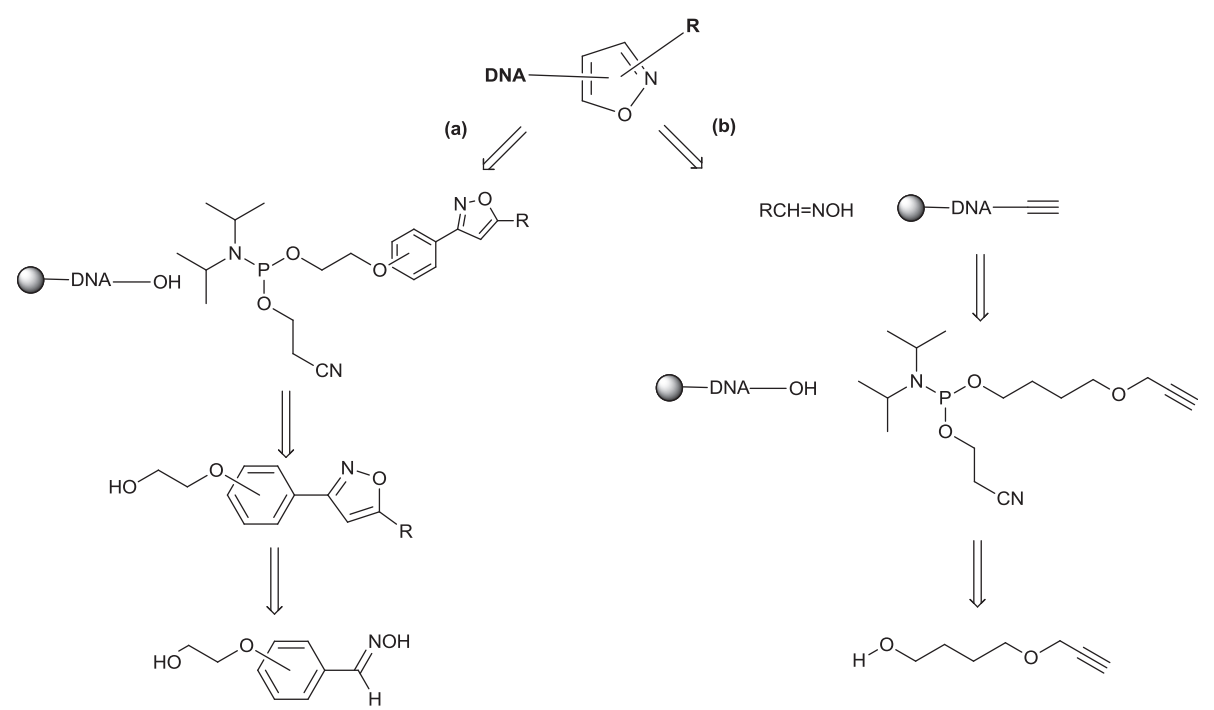

Fig. 1. Retrosynthetic approaches to chemically modified oligonucleotides involving (a) off-resin and (b) on-resin nitrile oxide-alkyne cycloaddition (NOAC) chemistry.<smiles>COC[C@H](C)OP(N=[Pt])OCCC#N</smiles>

Fig. 2. Isoxazole phosphoramidite, $\mathbf{1}^{17}$

since all three regioisomers, with their varying steric demands, could be obtained.

The desired oximes $\mathbf{2}$ were prepared in excellent yields (88-96\%) from commercially available aldehyde precursors 3 following reaction with hydroxylamine hydrochloride in the presence of sodium acetate. For each oxime, in situ generation of the corresponding nitrile oxide was achieved through reaction with chloramine-T in aqueous ethanol. The transient dipole was trapped with propargyl phenyl ether and the cycloaddition products, $\mathbf{4 a - c}$ were obtained in $81-85 \%$ isolated yield following stirring at room temperature, Scheme 1. In each case reaction was, as expected, highly selective for formation of the 5-substituted isomer. Regiochemical assignment of the major isomer follows from the resonance position of the isoxazole ring proton, which presents as a singlet in the range 6.59-6.76 ppm. This chemical shift is typical of an isoxazole $\mathrm{H}-4$ proton; a proton at the $\mathrm{C}-5$ position is expected to resonate more downfield, somewhere in the region of
$7.50-8.50 \mathrm{ppm},{ }^{18-20}$ indeed, in each case low intensity signals, at $\sim 8.5 \mathrm{ppm}$ in the ${ }^{1} \mathrm{H}$ NMR spectrum of the crude cycloaddition products provides evidence for minor amounts of the 4-substituted regioisomers 5. Further, singlet resonances appearing at $\sim 4.9 \mathrm{ppm}$, are deemed characteristic of the methylene protons adjacent to the isoxazole ring. The regioselectivity of the reaction ranges from $44: 1$ to $27: 1$ in favour of the 5-substituted isomers 4 .

The regioisomeric phosphoramidite monomers 6 were prepared, in reasonable yields, from the corresponding isoxazole building blocks 4 following reaction with 2-cyanoethyl- $N, N, N^{\prime}, N^{\prime}-$ tetraisopropylphosphorodiamidite in anhydrous acetonitrile. Benzylmercaptotetrazole (BMT) was employed as activator in the presence of diisopropylamine (Scheme 1). Following $30 \mathrm{~min}$ at room temperature, TLC analysis indicated complete consumption of the starting alcohol. ${ }^{31} \mathrm{P}$ NMR spectroscopy demonstrated phosphorus resonances at $\sim 148-149 \mathrm{ppm}$, supporting formation of the desired monomers. Purification of phosphoramidites by flash column chromatography can be tricky; to avoid decomposition and erosion in yield, rapid elution under a stream of an inert gas is required. For synthetic purposes we have found $\mathbf{6 a}-\mathbf{c}$ were suitable for manual solid phase coupling without purification. The unpurified isoxazole phosphoramidite monomers, $\mathbf{6}$, were introduced to resin bound nucleoside/oligonucleotide substrates (Scheme 2). Initial experimentation focused on reaction between CPG-(controlled pore glass)-supported thymidine and the $o$-substituted isoxazole phosphoramidite $\mathbf{6 a}$. Reaction was achieved by manual solid phase coupling on a $1 \mu \mathrm{mol}$ scale. The thymidine loaded resin,
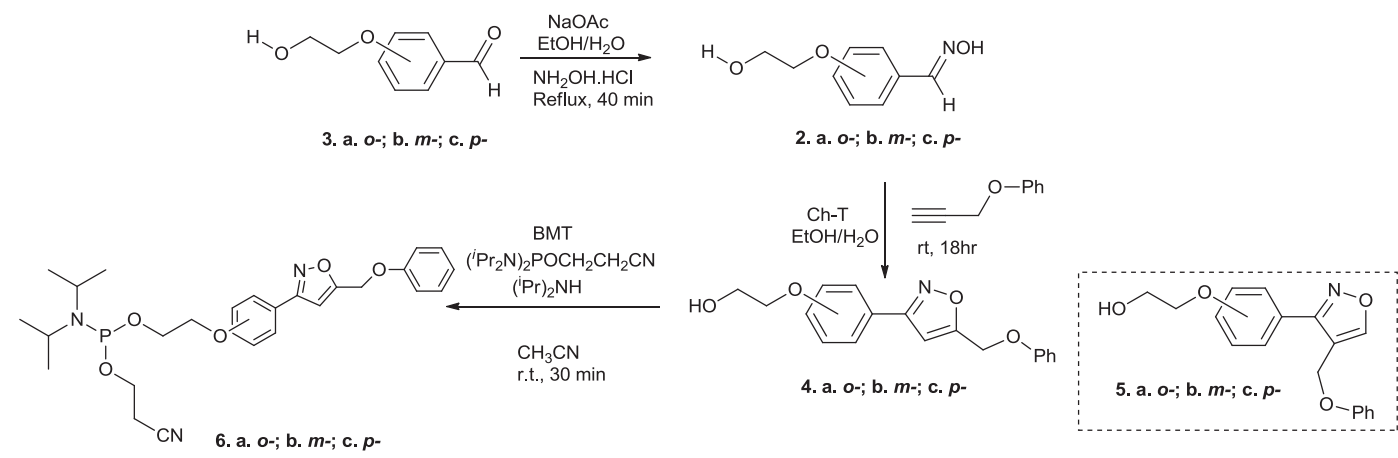

Scheme 1. Synthesis of the phosphoramidite monomers 6 
7, was placed in a DNA synthesis column and a $1 \mathrm{~mL}$ syringe containing an acetonitrile solution of the required phosphoramidite was attached to one end. A second syringe, containing a solution of the activator, benzylmercaptotetrazole, was attached to the other end. The solutions were passed through the column over a period of 15 min with mixing between the two syringes. To ensure complete reaction the procedure was repeated with a second portion of each of a new solution of the phosphoramidite and the activator. Following the second 15 min period of mixing at room temperature oxidation preceeded cleavage of the reaction product from the resin 8a. The coupling yield of crude product $\mathbf{9}$, Fig. 3, was judged from the HPLC profile of the raw material to be higher than $95 \%$. four DNA bases with their standard protecting groups, was selected to establish the general applicability of the concept. As described above, during a $30 \mathrm{~min}$ period, separate solutions of the phosphoramidite monomer $\mathbf{6 a}$ and the activator were manually passed over the resin-supported material $\mathbf{1 3}$ contained in a DNA synthesis column. The oligonucleotide was then deprotected and removed from the solid support 14a following treatment with ammonium hydroxide ( $24 \mathrm{~h}$, room temperature). Significantly, HPLC analysis of the unpurified reaction product indicated quantitative conversion of 13 to $15 a$, Fig. 4.

In a further examination of the generality of this approach the regioisomeric phosphoramidites $\mathbf{6 b}$ and $\mathbf{6 c}$ were successfully in-

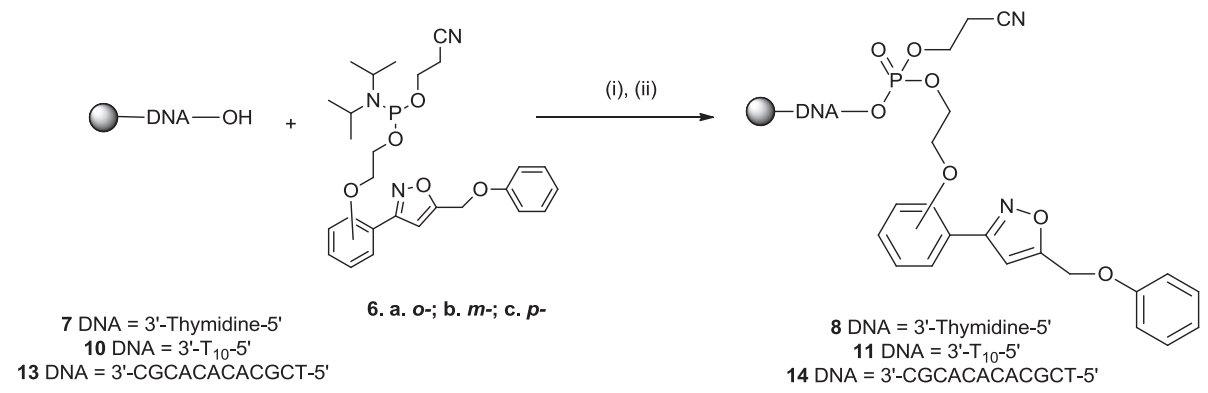

(i) $\mathrm{BMT},{ }^{i} \mathrm{Pr}_{2} \mathrm{NH}, \mathrm{CH}_{3} \mathrm{CN}$, r.t., 30 min. (ii) $\mathrm{I}_{2}(0.1 \mathrm{M})$ THF-pyridine- $\mathrm{H}_{2} \mathrm{O}$.

Scheme 2. Solid phase synthesis of chemically modified oligonucleotides using previously clicked isoxazole phosphoramidite monomers.

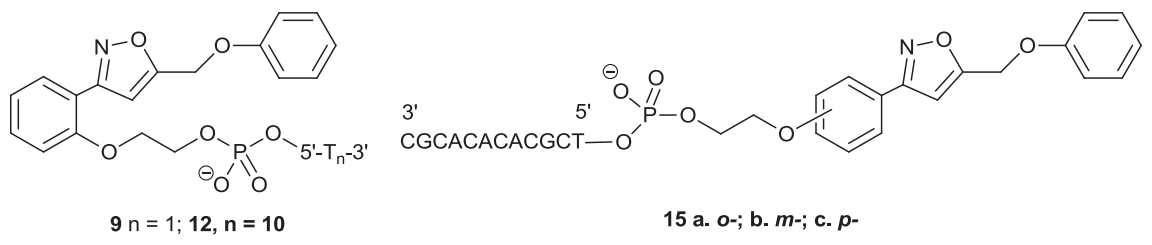

Fig. 3. Structures of isoxazole modified oligonucleotides.

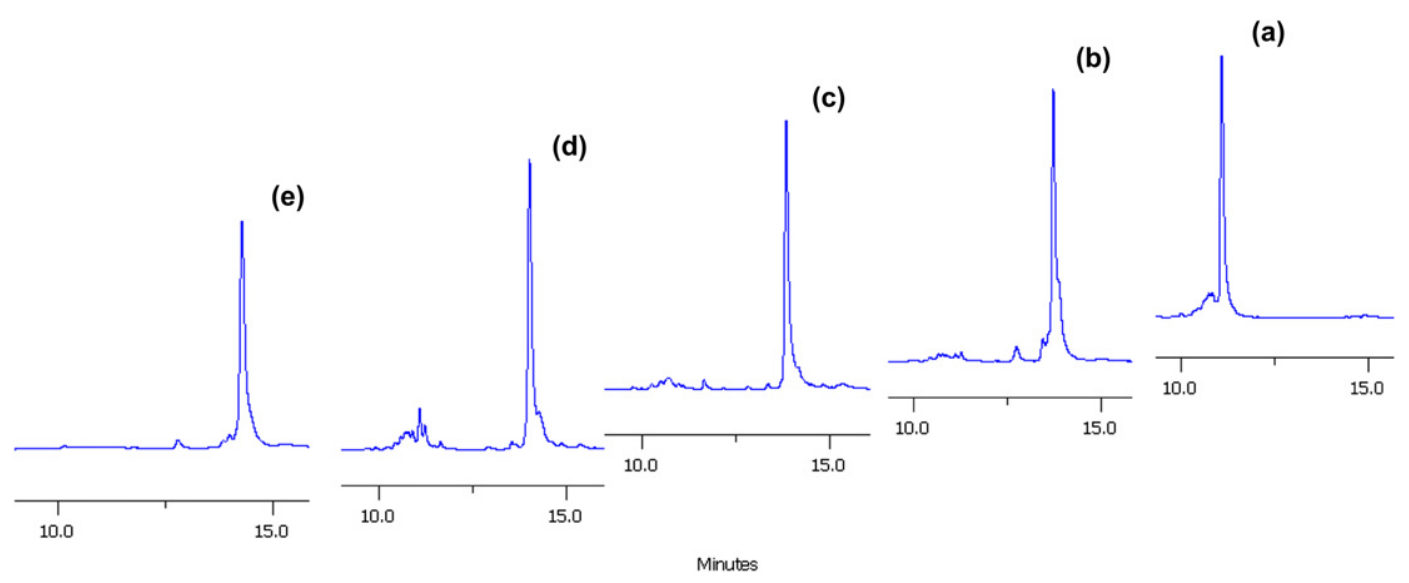

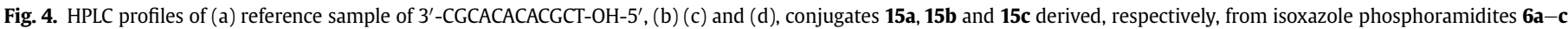
and prepared by manual solid phase synthesis (e) $15 c$ prepared on a DNA synthesizer.

To establish compatibility with an oligonucleotide, reaction with CPG-loaded decathymidine, 10, was examined. Gratifingly, under the same conditions, reaction with the 10-mer substrate was found to proceed smoothly, and following cleavage of the DNA from 11a HPLC analysis of the unpurified reaction product indicated $\mathbf{1 2}$ was present in essentially quantitative yield.

To further probe the scope of the reaction a CPG-supported 12mer oligonucleotide $\mathbf{1 3}$ was examined. The sequence, bearing all corporated into the resin-supported mixed base 12-mer 13 by manual solid phase synthesis. In each case, cleavage and deprotection of the supported products, $\mathbf{1 4 b}$,c was effected by treatment with ammonium hydroxide. HPLC analysis, Fig. 4, confirmed complete consumption of starting material and selective formation of the products $\mathbf{1 5 b}, \mathbf{c}$.

The potential to automate the coupling was established on an Expedite DNA synthesizer using purified samples of the isoxazole 
phosphoramidites. The conjugate 15c was formed in excess of $90 \%$ yield from reaction between $\mathbf{6 c}$ and resin supported $\mathbf{1 3}(0.2 \mu \mathrm{mol})$ using the standard instrument protocol, viz. 37 equiv of phosphoramidite and 1.5 min coupling time. However, to achieve the same level of conjugation with the sterically more demanding substrates $\mathbf{6 a}$ and $\mathbf{6 b}$ more generous conditions were required, viz. 50 equiv of phosphoramidite and $15 \mathrm{~min}$ coupling time. HPLC analysis shows a favourable comparison between the manual and automated approaches; in all cases, greater than $90 \%$ incorporation of the non-natural phosphoramidites was observed; comparative data are shown for samples of $\mathbf{1 5 c}$ prepared by both approaches, Fig. 4, (d) and (e).

All new conjugates, 9a, 12a and 15a-c derived from the isomeric phosphoramidites $\mathbf{6}$ were characterized by mass spectrometry (ESIMS or MALDI-TOF MS), and most importantly, in all cases yields of conjugates derived from isoxazoles generated off-resin, Fig. 1 (a), compare favourably with those obtained for similar conjugates constructed by on-resin click cycloaddition chemistry with alkyne modified DNA substrates, Fig. 1, path (b). ${ }^{4}$

\section{Conclusion}

Novel isoxazole building blocks were generated by $\mathrm{Cu}$-free nitrile oxide-alkyne cycloadditions. Following conversion to phosphoramidites, incorporation into oligonucleotides has been achieved manually on the solid phase and on a DNA synthesizer employing a standard protocol. The coupling reaction is efficient both at the monomeric level (CPG-Thymidine) and for oligonucleotides (CPG-12-mer DNA). Whilst on-resin functionalisation of alkyne modified oligonucleotides by nitrile oxide or CuAAC click chemistry is already established as a powerful method for oligonucleotide conjugation, for some applications it may be more attractive to assemble the conjugate from phosphoramidite building blocks previously prepared by click chemistry. Possible advantages may ensue in terms of cost, ease of operation and enhanced potential for scale-up. ${ }^{21}$

\section{General experimental}

Analytical TLC was performed on precoated $(250 \mu \mathrm{m})$ silica gel $60 \mathrm{~F}_{254}$ plates from Merck. All plates were visualized by UV irradiation, and/or staining with $5 \% \mathrm{H}_{2} \mathrm{SO}_{4}$ in ethanol followed by heating. Flash chromatography was performed using silica gel 32-63 $\mu \mathrm{m}, 60 \AA$. Mass analysis was performed on an Agilent Technologies 6410 Time of Flight LC/MS. MALDI-TOF mass data was acquired on an Applied Biosystem Voyager instrument or a LASERTOF LT3 from Scientific Analytical Instruments with 3hydroxypicolinic acid or $2^{\prime}, 4^{\prime}, 6^{\prime}$-trihydroxyacetophenone as matrix. NMR spectra were obtained on a Bruker instrument at $25{ }^{\circ} \mathrm{C}$ $\left({ }^{1} \mathrm{H}\right.$ at $300 \mathrm{MHz} ;{ }^{13} \mathrm{C}$ at $75 \mathrm{MHz} ;{ }^{31} \mathrm{P}$ at $\left.121 \mathrm{MHz}\right)$. Chemical shifts are reported in parts per million downfield from TMS as standard. All NMR spectra are recorded in $\mathrm{CDCl}_{3}$. HPLC was carried out using a Gilson instrument equipped with a diode array detector and a Nucleosil C18 column $(4.0 \times 250 \mathrm{~mm})$. Automated oligonucleotide synthesis was carried out on an Expedite nucleic acid synthesis system.

\subsection{General procedure for preparation of oximes $2 a-c$}

A solution of the required aryl aldehyde $3 \mathbf{a}-\mathbf{c}(1.00 \mathrm{~g}$, $6.02 \mathrm{mmol}$ ) and hydroxylamine hydrochloride $(1.26 \mathrm{~g}, 18.1 \mathrm{mmol})$ in EtOH (35 mL) was stirred at room temperature for $10 \mathrm{~min}$, after which a solution of sodium acetate $(1.69 \mathrm{~g}, 24.1 \mathrm{mmol})$ in $\mathrm{H}_{2} \mathrm{O}$ $(15 \mathrm{~mL})$ was added. The mixture was heated under reflux for $40 \mathrm{~min}$. Following solvent removal under reduced pressure the crude product, obtained as a white solid, was taken up in EtOAc
(30 mL), washed with $\mathrm{H}_{2} \mathrm{O}(3 \times 20 \mathrm{~mL})$ and dried over anhydrous magnesium sulfate. Removal of the solvent under reduced pressure yielded the pure product as a white solid in excellent yield.

4.1.1. 2-(2-Hydroxyethoxy)benzaldehyde oxime, 2a. White solid (96\%), mp 98-100 ${ }^{\circ} \mathrm{C}, R_{f}=0.44$ (hexane/EtOAc, 3:7); ${ }^{1} \mathrm{H}$ NMR $\delta 8.39(\mathrm{~s}, 1 \mathrm{H}, \mathrm{HC}=\mathrm{N}), 7.54(\mathrm{dd}, J=7.7,1.7 \mathrm{~Hz}, 1 \mathrm{H}, \mathrm{ArH}), 7.38-7.32$ (m, 1H, ArH), 7.04-6.95 (m, 2H, ArH), 4.17 (t, J=4.2 Hz, 2H, CH $\mathrm{CH}_{2}$, $3.98\left(\mathrm{t}, J=4.2 \mathrm{~Hz}, 2 \mathrm{H}, \mathrm{CH}_{2}\right) ;{ }^{13} \mathrm{C}$ NMR $\delta 157.0,147.8,131.2,128.9$, 121.6, 121.2, 113.7, 70.7, 61.2; IR ( $\mathrm{KBr}) 3388,3219,1601,1251$, $764 \mathrm{~cm}^{-1}$; HRMS (ESI) calcd for $[\mathrm{M}+\mathrm{Na}]^{+}, \mathrm{C}_{9} \mathrm{H}_{11} \mathrm{NO}_{3} \mathrm{Na}, 204.0631$, found 204.0640 .

4.1.2. 3-(2-Hydroxyethoxy)benzaldehyde oxime, $\mathbf{2 b}$. White solid (86\%), mp 94-96 ${ }^{\circ} \mathrm{C}, R_{f}=0.44$ (hexane/EtOAc, 3:7); ${ }^{1} \mathrm{H}$ NMR $\delta 8.10$ (s, $1 \mathrm{H}, \mathrm{HC}=\mathrm{N}$ ), 7.59 (br s, 1H, OH), 7.33-7.28 (m, 1H, ArH), 7.19-7.13 $(\mathrm{m}, 2 \mathrm{H}, \mathrm{ArH}), 6.96$ (dd, $J=9.0,2.4 \mathrm{~Hz}, 1 \mathrm{H}, \mathrm{ArH}), 4.12(\mathrm{t}, J=4.2 \mathrm{~Hz}, 2 \mathrm{H}$, $\left.\mathrm{CH}_{2}\right), 3.98\left(\mathrm{t}, J=4.2 \mathrm{~Hz}, 2 \mathrm{H}, \mathrm{CH}_{2}\right) ;{ }^{13} \mathrm{C}$ NMR $\delta 156.9,147.7,131.2,128.8$, 121.6, 121.2, 113.6, 70.6, 61.2; IR (KBr) 3350, 3154, 1595, 1262, 907, $795 \mathrm{~cm}^{-1}$; HRMS (ESI) calcd for $[\mathrm{M}+\mathrm{H}]^{+}, \mathrm{C}_{9} \mathrm{H}_{12} \mathrm{NO}_{3}, 182.0812$, found 182.0809 .

4.1.3. 4-(2-Hydroxyethoxy)benzaldehyde oxime, 2c. White solid (88\%), mp 109-111 ${ }^{\circ} \mathrm{C}, R_{f}=0.40$ (hexane/EtOAc, 3:7); ${ }^{1} \mathrm{H}$ NMR $\delta 8.09$ $(\mathrm{s}, 1 \mathrm{H}, \mathrm{HC}=\mathrm{N}), 7.51(\mathrm{~d}, J=8.8 \mathrm{~Hz}, 2 \mathrm{H}, \mathrm{ArH}), 7.32(\mathrm{br} \mathrm{s}, 1 \mathrm{H}, \mathrm{OH}), 6.93$ $(\mathrm{d}, J=8.8 \mathrm{~Hz}, 2 \mathrm{H}, \mathrm{ArH}), 4.12\left(\mathrm{t}, J=4.8 \mathrm{~Hz}, 2 \mathrm{H}, \mathrm{CH}_{2}\right), 3.98(\mathrm{t}, J=4.8 \mathrm{~Hz}$, $\left.2 \mathrm{H}, \mathrm{CH}_{2}\right) ;{ }^{13} \mathrm{C}$ NMR $\delta$ 160.1, 149.9, 128.5, 125.2, 114.8, 69.3, 61.4; IR (KBr) 3262, 1605, 1259, $836 \mathrm{~cm}^{-1}$; HRMS (ESI) calcd for $\mathrm{C}_{9} \mathrm{H}_{11} \mathrm{NO}_{3} \mathrm{Na},[\mathrm{M}+\mathrm{Na}]^{+}, 204.0631$, found 204.0622 .

\subsection{General procedure for preparation of cycloadducts 4}

The required oxime $\mathbf{2 a}-\mathbf{c}(500 \mathrm{mg}, 2.76 \mathrm{mmol})$ was dissolved in EtOH $(2.5 \mathrm{~mL})$ and to this solution was added propargyl phenyl ether (182 mg, $1.38 \mathrm{mmol}$ ), chloramine $\mathrm{T}$ ( $785 \mathrm{mg}, 3.45 \mathrm{mmol}$ ) and $\mathrm{H}_{2} \mathrm{O}(2.5 \mathrm{~mL})$ The mixture was stirred for $2 \mathrm{~h}$ at room temperature after which analysis by TLC (hexane/EtOAc, 3:7) indicated complete reaction. After removal of the solvent under reduced pressure, the residue was taken up in EtOAc $(30 \mathrm{~mL})$ and the solution was washed with $5 \% \mathrm{NaOH}(3 \times 10 \mathrm{~mL})$. The organic layer was dried over anhydrous magnesium sulfate and the solvent was removed under reduced pressure. The crude products were purified by flash column chromatography (hexane/EtOAc, 3:7) to give the cycloadduct in good yield.

4.2.1. 2-\{2-[5-(Phenoxymethyl)isoxazol-3-yl]phenoxy $\}$ ethanol, 4a. Colourless oil (81\%), $R_{f}=0.54$ (hexane/EtOAc, 3:7); ${ }^{1} \mathrm{H}$ NMR $\delta 7.71$ (dd, $J=7.6,1.3 \mathrm{~Hz}, 1 \mathrm{H}$, ArH ), 7.42-7.29 (m, 3H, ArH), 7.08-6.97 $(\mathrm{m}, 5 \mathrm{H}, \mathrm{ArH}), 6.76\left(\mathrm{~s}, 1 \mathrm{H}\right.$, isox-H), $5.20\left(\mathrm{~s}, 2 \mathrm{H}, \mathrm{CH}_{2}\right), 4.18(\mathrm{t}, J=4.2 \mathrm{~Hz}$, $2 \mathrm{H}, \mathrm{CH}_{2}$ ), 3.92 (br s, $2 \mathrm{H}, \mathrm{CH}_{2}$ ), 3.24 (br s, $1 \mathrm{H}, \mathrm{OH}$ ); ${ }^{13} \mathrm{C}$ NMR $\delta 167.4$, 160.4, 157.8, 156.7, 131.4, 129.8, 129.7, 121.8, 121.6, 118.4, 114.8, 113.9, 104.2, 70.9, 61.3, 61.1; IR (film) 3400, 1601, 1245, $755 \mathrm{~cm}^{-1}$; HRMS (ESI) calcd for $\mathrm{C}_{18} \mathrm{H}_{18} \mathrm{NO}_{4},[\mathrm{M}+\mathrm{H}]^{+}, 312.1230$, found 312.1242 .

4.2.2. 2-\{3-[5-(Phenoxymethyl)isoxazol-3-yl]phenoxy\}ethanol, 4b. White solid (81\%), $\mathrm{mp} 70-72{ }^{\circ} \mathrm{C}, R_{f}=0.52$ (hexane/EtOAc, 3:7); ${ }^{1} \mathrm{H}$ NMR $\delta$ 7.39-7.28 (m, 5H, ArH), 7.03-6.96 (m, 4H, ArH), $6.61(\mathrm{~s}$, $1 \mathrm{H}$, isox-H), $5.17\left(\mathrm{~s}, 2 \mathrm{H}, \mathrm{CH}_{2}\right), 4.12\left(\mathrm{t}, J=4.2 \mathrm{~Hz}, 2 \mathrm{H}, \mathrm{CH}_{2}\right), 3.96$ (br s, $\left.2 \mathrm{H}, \mathrm{CH}_{2}\right) 2.42$ (br s, $1 \mathrm{H}, \mathrm{OH}$ ); ${ }^{13} \mathrm{C}$ NMR $\delta 168.7,162.4,159.1,157.8$, $130.1,130.0,129.7,121.9,119.8,116.8,114.8,112.5,101.5,69.4,61.4$, $61.3 \mathrm{~cm}^{-1}$; IR (KBr) 3208, 1600, 1260, 1231, 885, $755 \mathrm{~cm}^{-1}$; HRMS (ESI) calcd for $\mathrm{C}_{18} \mathrm{H}_{18} \mathrm{NO}_{4},[\mathrm{M}+\mathrm{H}]^{+}, 312.1230$, found 312.1233.

4.2.3. 2-\{4-[5-(Phenoxymethyl)isoxazol-3-yl]phenoxy\}ethanol, 4c. White solid (85\%), mp 95-97 ${ }^{\circ} \mathrm{C}, R_{f}=0.49$, (hexane/EtOAc, 3:7); ${ }^{1} \mathrm{H}$ NMR $\delta 7.74(\mathrm{~d}, J=8.6 \mathrm{~Hz}, 2 \mathrm{H}, \mathrm{ArH}), 7.32(\mathrm{t}, J=7.7 \mathrm{~Hz}, 2 \mathrm{H}, \mathrm{ArH})$, 
7.04-6.98 (m, 5H, ArH), 6.59 (s, 1H, isox-H), $5.20\left(\mathrm{~s}, 2 \mathrm{H}, \mathrm{CH}_{2}\right), 4.13(\mathrm{t}$, $J=4.2 \mathrm{~Hz}, 2 \mathrm{H}, \mathrm{CH}_{2}$ ), 3.99 (t, $J=4.2 \mathrm{~Hz}, 2 \mathrm{H}, \mathrm{CH}_{2}$ ), 2.04 (br s, $1 \mathrm{H}, \mathrm{OH}$ ); ${ }^{13} \mathrm{C}$ NMR $\delta 168.4,162.1,160.1,157.8,129.7,128.3,121.9,121.7,114.9$, 114.8, 101.1, 69.3, 61.5, 61.4; IR (KBr), 3438, 1613, 1258, 1238, $842 \mathrm{~cm}^{-1}$; HRMS (ESI) calcd for $\mathrm{C}_{18} \mathrm{H}_{18} \mathrm{NO}_{4},[\mathrm{M}+\mathrm{H}]^{+}, 312.1230$, found 312.1245 .

\subsection{General procedure for preparation of phosphoramidites 6}

The required cycloadduct $\mathbf{4 a}-\mathbf{c}(100 \mathrm{mg}, 0.321 \mathrm{mmol})$, and benzylmercaptotetrazole $(31 \mathrm{mg}, 0.159 \mathrm{mmol}$ ) were placed in a dried round bottomed flask under an argon atmosphere.

Anhydrous acetonitrile $(5 \mathrm{~mL})$ was added to the flask followed by diisopropylamine $(23 \mu \mathrm{l}, 0.162 \mathrm{mmol})$ and 2-cyanoethyl$N, N, N^{\prime}, N^{\prime}$-tetraisopropylphosphorodiamidite (112 $\left.\mu \mathrm{l}, 0.353 \mathrm{mmol}\right)$. The reaction mixture was stirred for $30 \mathrm{~min}$ at room temperature after which TLC analysis (hexane/EtOAc, 3:7) showed complete consumption of the starting alcohol. The reaction mixture was diluted with ethyl acetate $(25 \mathrm{~mL})$ and washed with aqueous sodium bicarbonate $(10 \times 3 \mathrm{~mL})$. The organic layer was dried over anhydrous sodium sulfate and the solvent was removed under reduced pressure to give the crude phosphoramidite, which was purified by flash column chromatography (hexane/EtOAc, 3:7) with elution under a positive pressure of nitrogen gas.

4.3.1. 2-Cyanoethyl 2-\{2-[5-(phenoxymethyl)isoxazol-3-yl]phenoxy\} ethyl $N, N$-diisopropylphosphoramidite, $6 \boldsymbol{a}$. Colourless oil, $R_{f}=0.83$ (hexane/EtOAc, 3:7); ${ }^{1} \mathrm{H}$ NMR $\delta 7.94$ (dd, $J=7.7,1.7 \mathrm{~Hz}, 1 \mathrm{H}, \mathrm{ArH}$ ), 7.43-7.31 (m, 3H, ArH), 7.07-6.98 ( $\mathrm{m}, 6 \mathrm{H}, \mathrm{ArH}$ and isox-H), 5.19 (s, $\left.2 \mathrm{H}, \mathrm{CH}_{2}\right), 4.25-4.22(\mathrm{~m}, 2 \mathrm{H}), 4.16-3.54(\mathrm{~m}, 6 \mathrm{H}), 2.55-2.51(\mathrm{~m}, 2 \mathrm{H})$, 1.19-1.14 (m, 12H); ${ }^{31} \mathrm{P}$ NMR $\delta 148.8$.

4.3.2. 2-Cyanoethyl 2-\{3-[5-(phenoxymethyl)isoxazol-3-yl]phenoxy\} ethyl N,N-diisopropylphosphoramidite, $6 \mathbf{b}$. Colourless oil, $R_{f}=0.83$ (hexane/EtOAc, 3:7); ${ }^{1} \mathrm{H} \delta$ NMR 7.39-7.32 (m, 5H, ArH), 7.05-6.98 $(\mathrm{m}, 4 \mathrm{H}, \mathrm{ArH}), 6.64\left(\mathrm{~s}, 1 \mathrm{H}\right.$, isox-H), $5.21\left(\mathrm{~s}, 2 \mathrm{H}, \mathrm{CH}_{2}\right), 4.20(\mathrm{t}, J=5.1 \mathrm{~Hz}$, $2 \mathrm{H}), 4.10-3.49(\mathrm{~m}, 6 \mathrm{H}), 2.63(\mathrm{t}, J=6.4 \mathrm{~Hz}, 2 \mathrm{H}), 1.20(\mathrm{dd}, J=6.8,2.1 \mathrm{~Hz}$, $12 \mathrm{H}) ;{ }^{31} \mathrm{P}$ NMR $\delta 149.1$.

4.3.3. 2-Cyanoethyl 2-\{4-[5-(phenoxymethyl)isoxazol-3-yl]phenoxy\} ethyl N,N-diisopropylphosphoramidite, 6c. Colourless oil, $R_{f}=0.83$ (hexane/EtOAc, 3:7); ${ }^{1} \mathrm{H}$ NMR $\delta 7.73$ (d, $\left.J=8.7 \mathrm{~Hz}, 2 \mathrm{H}, \mathrm{ArH}\right), 7.32(\mathrm{t}$, $J=7.6 \mathrm{~Hz}, 2 \mathrm{H}, \mathrm{ArH}), 7.04-6.95(\mathrm{~m}, 5 \mathrm{H}, \mathrm{ArH}), 6.59(\mathrm{~s}, 1 \mathrm{H}$, isox-H) 5.20 $\left(\mathrm{s}, 2 \mathrm{H}, \mathrm{CH}_{2}\right), 4.29\left(\mathrm{t}, J=5.1 \mathrm{~Hz}, 2 \mathrm{H}, \mathrm{CH}_{2}\right), 4.10-3.77(\mathrm{~m}, 4 \mathrm{H})$, $3.70-3.57(\mathrm{~m}, 2 \mathrm{H}), 2.63(\mathrm{t}, J=6.5 \mathrm{~Hz}, 2 \mathrm{H}), 1.20(\mathrm{dd}, J=6.8,2.9 \mathrm{~Hz}$, $12 \mathrm{H}) ;{ }^{31} \mathrm{P}$ NMR $\delta 149.0$.

\subsection{General procedure for the phosphitylation of CPG-DNA- OH $5^{\prime}$, preparation of 8,11 and $14 a-c$}

Option 1. To manually couple the phosphoramidites $\mathbf{6 a}-\mathbf{c}$ to the resin supported nucleoside/oligonucleotide, $\mathbf{7 , 1 0}$ or $\mathbf{1 3}$, separate solutions of the phosphoramidite $(500 \mu \mathrm{L}, 100 \mathrm{mM}$ in anhyd $\left.\mathrm{CH}_{3} \mathrm{CN}\right)$ and of benzylmercaptotetrazole $(500 \mu \mathrm{L}, 0.3 \mathrm{mM}$ in anhyd $\mathrm{CH}_{3} \mathrm{CN}$ ), both in $1 \mathrm{~mL}$ syringes were attached to either end of a DNA synthesis column containing CPG-DNA $(1 \mu \mathrm{mol})$. The mixture was reacted for $15 \mathrm{~min}$ at room temperature with mixing between the two syringes. This reaction was repeated with a second portion of each of a new solution of the phosphoramidite and benzylmercaptotetrazole. The $\mathrm{CPG}$ was washed with $\mathrm{CH}_{3} \mathrm{CN}(5 \times 2 \mathrm{~mL})$ prior to treatment with oxidizer $(700 \mu \mathrm{L}, 0.1 \mathrm{M}$ Iodine solution in THF/pyridine/water; 78:20:2). Further washing with $\mathrm{CH}_{3} \mathrm{CN}(2 \times 5 \mathrm{~mL})$ and drying yielded CPG-DNA-isoxazole conjugates 8, 11 and 14a-c.

Option 2. Automated coupling of the phosphoramidites $\mathbf{6 a}-\mathbf{c}$ to the resin supported oligonucleotide, 13, was achieved using an Expedite Nucleic Acid Synthesis System using standard instrument protocols. All reactions were conducted on a scale involving CPGDNA $(0.2 \mu \mathrm{mol})$. For coupling $\mathbf{6 a}, \mathbf{b} 50$ equiv of phosphoramidite were used and 15 min coupling time. For coupling $6 \mathbf{c} 37$ equiv of phosphoramidite were used and 1.5 min coupling time.

\subsection{General deprotection procedure, preparation of 9,12 and $15 a-c$}

For analytical purposes a portion of the DNA was deprotected and cleaved from the CPG by incubating the CPG-DNA in either

i $40 \%$ aqueous $\mathrm{CH}_{3} \mathrm{NH}_{2}(500 \mu \mathrm{L})$ at $65^{\circ} \mathrm{C}$ for $30 \mathrm{~min}$ (for substrates $\mathbf{8}$ and $\mathbf{1 1}$ )

ii. $28 \%$ aqueous $\mathrm{NH}_{4} \mathrm{OH}\left(1 \mathrm{~mL}\right.$ ) at $25^{\circ} \mathrm{C}$ for $24 \mathrm{~h}$ (for substrates $14 a-c)$

As appropriate, $\mathrm{CH}_{3} \mathrm{NH}_{2} / \mathrm{NH}_{4} \mathrm{OH}$ was evaporated using a concentrator. The CPG was washed with $\mathrm{H}_{2} \mathrm{O}(3 \times 150 \mu \mathrm{L}$ aliquots $)$, all solutions and washings were combined to afford an aqueous solution of DNA-alkynes $\mathbf{9}, 12$ and $15 a-c$. On analysis by HPLC retention times $\left(t_{\mathrm{R}}\right)$ of the starting nucleosides/oligonucleotides and the modified conjugates are as follows.

Thymidine $t_{\mathrm{R}}=22.7 \mathrm{~min}, 9 t_{\mathrm{R}}=16.5 \mathrm{~min}$.

Decathymidine $t_{\mathrm{R}}=12.3 \mathrm{~min}, \mathbf{1 2} t_{\mathrm{R}}=16.0 \mathrm{~min}$.

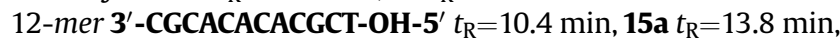
15b $t_{\mathrm{R}}=13.9 \mathrm{~min}, \mathbf{1 5 c} t_{\mathrm{R}}=14.0 \mathrm{~min}$.

Compound 9 HRMS (ESI) $m / z$ calcd for $638.1510[\mathrm{M}+\mathrm{Na}]^{+}$; found 638.1534 .

Compound 12 MALDI-TOF-MS m/z: calcd 3353; found 3353.

Compound 15a MALDI-TOF-MS $m / z$ : calcd 3948; found 3949.

Compound 15b MALDI-TOF-MS $m / z$ : calcd 3948; found 3949.

Compound 15c MALDI-TOF-MS m/z: calcd 3948; found 3949.

\subsection{General method for HPLC analysis}

Nucleoside and oligonucleotide conjugates were analyzed by reverse-phase HPLC under the following conditions; $200 \mu \mathrm{L}$ injection loop; buffer A: $0.1 \mathrm{M}$ TEAAc, $\mathrm{pH} 6.5,5 \%(\mathrm{v} / \mathrm{v}) \mathrm{MeCN}$; buffer B: 0.1 M TEAAc, pH 6.5, 65\% (v/v) MeCN; Gradient: 0-4.3 min, 5\% B; 4.3-16.6 $\mathrm{min}, 5-100 \% \mathrm{~B}$; flow rate: $1.0 \mathrm{~mL} / \mathrm{min}$ and detection at $260 \mathrm{~nm}$.

\section{Acknowledgements}

Financial support from the Science Foundation of Ireland (Programme code 05/PICA/B838) is gratefully acknowledged. C.F. is grateful to the Irish Research Council Science and Engineering for receipt of an Embark Postgraduate Research Scholarship (Programme code RS/2007/48). A.N.C. acknowledges support from the Science Foundation Ireland UREKA Programme (SFI/08/ UR/F1353).

\section{Supplementary data}

Supplementary data associated with this article can be found in the online version, at doi:10.1016/j.tet.2011.06.096. These data include MOL files and InChiKeys of the most important compounds described in this article.

\section{References and notes}

1. El-Sagheer, A. H.; Brown, T. Chem. Soc. Rev. 2010, 39, 1388-13405.

2. Algay, V.; Singh, I.; Heaney, F. Org. Biomol. Chem. 2010, 8, 391-397.

3. Singh, I.; Zarafshani, Z.; Lutz, J.-F.; Heaney, F. Macromolecules 2009, 42, 5411-5413.

4. Singh, I.; Vyle, J. S.; Heaney, F. Chem. Commun. 2009, 3276-3278.

5. Gutsmiedl, K.; Fazio, D.; Carell, T. Chem.-Eur. J. 2010, 16, 6877-6883. 
6. Gutsmiedl, K.; Wirges, C. T.; Ehmke, V.; Carell, T. Org. Lett. 2009, 11, 2405-2408.

7. Karskela, M.; Helkearo, M.; Virta, P.; Loennberg, H. Bioconjugate Chem. 2010, 21, 748-755.

8. Kocalka, P.; Andersen, N. K.; Jensen, F.; Nielsen, P. ChemBioChem 2007, 8 , 2106-2116.

9. Andersen, N. K.; Chandak, N.; Brulikova, L.; Kumar, P.; Jensen, M. D.; Jensen, F. Sharma, P. K.; Nielsen, P. Bioorg. Med. Chem. Lett. 2010, 18, 4702-4710.

10. Ostergaard, M. E.; Guenther, D. C.; Kumar, P.; Baral, B.; Deobald, L.; Paszczynski, A. J.; Sharma, P. K.; Hrdlicka, P. J. Chem. Commun. 2010, 4929-4931.

11. Andersen, N. K.; Spacilova, L.; Jensen, M. D.; Kocalka, P.; Jensen, F.; Nielsen, P. Nucleic Acids Symp. Ser. 2008, 52, 149-150.

12. James, D.; Escudier, J.-M.; Amigues, E.; Schulz, J.; Vitry, C.; Bordenave, T.; Szlosek-Pinaud, M.; Fouquet, E. Tetrahedron Lett. 2010, 51, 1230-1232.

13. Godeau, G.; Staedel, C.; Barthelemy, P. J. Med. Chem. 2008, 51, 4374-4376.
14. Chittepu, P.; Sirivolu, V. R.; Seela, F. Bioorg. Med. Chem. Lett. 2008, 16, 8427-8439.

15. Seela, F.; Sirivolu, V. R. Nucleosides, Nucleotides Nucleic Acids 2007, 26, 597-601.

16. Werder, S.; Malinovskii, V. L.; Haener, R. Org. Lett. 2008, 10, 2011-2014.

17. Smietana, M.; Johnson, R. B.; Wang, Q. M.; Kool, E. T. Chem.-Eur. J. 2004, 10, $173-181$.

18. Grecian, S.; Fokin, V. V. Angew. Chem., Int. Ed. 2008, 47, 8285-8287.

19. Lee, Y.-S.; Hyean Kim, B. Bioorg. Med. Chem. Lett. 2002, 12, 1395-1397.

20. Himo, F.; Lovell, T.; Hilgraf, R.; Rostovtsev, V. V.; Noodleman, L.; Sharpless, K. B.; Fokin, V. V. J. Am. Chem. Soc. 2005, 127, 210-216.

21. Part of this work was discussed at the XVth symposium on chemistry of nucleic acid components Freeman, C.; Ni Cheallaigh, A.; Singh, I.; Heaney, F. In Collection Symposium Series; Hocek, M., Ed.; Institute of Organic Chemistry and Biochemistry, Academy of Sciences of the Czech Republic: Prague, 2011; Vol. 12, pp 333-333. 